\title{
PERAN KEPALA SEKOLAH DALAM PENINGKATAN MUTU PENDIDIKAN PERSPEKTIF MANAJEMEN MUTU TERPADU STUDI KASUS DI SDUT BUMI KARTINI JEPARA
}

\author{
Nur Rohman \\ Universitas Islam Nahdlatul Ulama Jepara \\ gnurrohman@gmail.com
}

\begin{abstract}
ABSTRAK
Penelitian ini bertujuan untuk mendiskripsikan peran kepala sekolah dalam peningkatan mutu pendidikan perspektif konsep manajemen mutu terpadu. Jenis penelitian yang dipakai menggunakan penelitian kualitatif. Subyek penelitian adalah kepala SDUT Bumi Kartini Jepara dengan menggunakan metode wawancara, observasi, dan dokumentasi. Hasil penelitian didapatkan bahwa kepala SDUT Bumi Kartini Jepara sudah menjalankan aspek-aspek Konsep Manajemen Mutu Terpadu diantaranya yaitu Pertama, peran sebagai perencanaan mutu kepala SDUT Bumi Kartini Jepara melakukan koordinasi kepada seluruh staf karyawan dan juga dewan guru dalam melakukan kegiatan, melibatkan seluruh komponen, menjelaskan tujuan yang akan dicapai, membentuk panitia-panitia, mengadakan monitoring dan mengadakan melakukan kegiatan. Kedua, peran sebagai pengendalian mutu kepala SDUT Bumi Kartini Jepara dilakukan dengan mengadakan evaluasi kinerja, membandingkan kinerja aktual dengan target, mengadakan rapat bulanan, menetapkan standar khusus dalam kinerja, memberikan reward dan punishment, memberikan arahan kepada pegawai, meminta laporan setelah kegiatan dan selalu memberikan motivasi kepada staf karyawan maupun dewan guru. Ketiga, peran sebagai perbaikan mutu dalam hal ini kepala SDUT Bumi Kartini Jepara mengadakan perbaikan terus menerus, mengadakan supervisi setiap persemester, memberikan pelatihan dan pendidikan kepada guru dan pegawai, mengadakan bimbingan belajar siswa pada jam luar sekolah dan bekerja sama dengan orang tua murid.
\end{abstract}

Kata Kunci: Peran Kepala Sekolah, Peningkatan Mutu Pendidikan dan Manajemen Mutu Terpadu

\section{ABSTRACT}

This study aims to describe the role of principals in improving the quality of education perspective of total quality management concepts. This type of research is the use of qualitative research. Jepara SDUT Bumi Kartini head of research subjects using interviews, observation, and documentation. The 
results showed that the head of SDUT Bumi Kartini Jepara has run aspects of Integrated Quality Management Concept among which are the First, the role as head of SDUT Bumi Kartini Jepara quality planning coordination to the entire staff of employees and also the board of teachers in conducting activities, involving all components, explains objectives to be achieved, forming committees, monitoring and held meetings every want to do activities. Second, the role as head of quality control SDUT Bumi Kartini Jepara in this case are Ernawati, M.Pd undertaken an evaluation of performance, comparing actual performance with targets, holding monthly meetings, specially in setting standards of performance, reward and panishment, provides guidance to employees, asking for a report after activity and always provide motivation to Setaf council employees and teachers. Third, the role of quality improvement in this case the head of SDUT Bumi Kartini Jepara conduct continuous improvement, conduct supervision per each semester, providing training and education to teachers and employees, held on the hour tutoring students outside of school and work closely with parents.

Keywords: Role of the Principal, Education Quality Improvement and Quality Management Concept 


\section{PENDAHULUAN}

Manajemen Mutu Terpadu merupakan suatu keinginan untuk selalu mencoba mengerjakan sesuatu dengan selalu baik sejak awal. (Edward Sallis, 2006:74). Sehingga ketika dari awal lembaga pendidikan mempersiapkan segala sesuatu-nya dengan baik maka pendidikan di sekolah tersebut akan lebih berkualitas. Sehingga mutu pendidikan merupakan salah satu pilar pembangunan sumberdaya manusia sangat penting bagi pembangunan nasional. Bahkan masa depan bangsa terletak pada keberadaan pendidikan yang berkualitas dan bermutu pada masa kini. Pendidikan yang bermutu hanya akan muncul apabila terdapat lembaga pendidikan yang benar-benar memperhatikan mutu pendidikan itu sendiri. Telah banyak contoh bahwa negara yang secara geografis kecil dan relative tidak mempunyai sumber daya alam tumbuh menjadi bangsa yang unggul karena kualitas lulusan dari sistem pendidikan yang dapat diandalkan, karena upaya menciptakan pendidikan yang bermutu. (Malik Fajar, 1999: 11)

Manajemen Mutu Terpadu (MMT) merupakan konsep yang mengutamakan kualitas/ mutu, tidak hanya diterapkan dalam dunia bisnis atau industri, tetapi akhirakhir ini juga telah diterapkan dalam dunia pedidikan. "Customers' satisfaction oriented", melalui optimalisasi dan aspek-aspek manajemen inilah yang menjadi obsesi dalam penerapan MMT, sehingga pelanggan (costumer) akan merasa puas dengan kualitas produk/ jasa yang dihasilkan. Memasuki era otonomi yang baru, sebagai sekolah swasta dibawah naungan yayasan diharapkan untuk bisa mandiri dan mampu untuk menggali potensi yang ada di dalam sekolahnya. Suatu tantangan yang patut mendapat respon dari pihak penyelenggara pendidikan swasta, agar di era otonomi mereka harus dapat mengoptimalkan kinerja tanpa ketergantungannya pada pemerintah. Pihak sekolah harus benar-benar menata kembali lembaga sekolah dengan manajemen modern dan profesional. Sekolah swasta harus benarbenar inovatif memberdayakan potensi sekolah di tengah masyarakat menampilkan produktivitas yang tinggi, sehingga ketergantungan tersebut bisa dikurangi. Sekolah merupakan salah satu tumpuan untuk memperbaiki sumber daya manusia.

Oleh karena itu, sekolah merupakan tempat utama dalam memperbaiki kualitas dan persiapan awal untuk menghadapi kompetisi yang ada pada zaman sekarang ini. Yaitu dengan cara menciptakan manajemen sekolah yang baik dan berkwalitas, karena manajemen sekolah adalah tempat untuk menciptakan kualitas dan keunggulan tersebut. Manajemen sekolah akan terlaksana jika didukung dengan

> | Nur Rohman| Peran Kepala Sekolah dalam Peningkatan Mutu Pendidikan Perspektif Manajemen Mutu Terpadu Studi Kasus di SDUT Bumi Kartini Jepara 
sumber daya manusia (SDM) yang memiliki kemampuan, integritas dan kemauan yang tinggi.

Dalam kerangka inilah dirasa perlu peningkatan kemampuan profesional kepala sekolah untuk mensukseskan program-program pemerintah yang digulirkan berkaitan dengan peningkatan mutu pendidikan. Untuk maksud itu, maka kepala sekolah harus memahami apa yang harus dicapai (visi) dan bagaimana mencapainya (misi). Kepala sekolah harus memiliki karakter yang menunjukkan integritasnya, segala bentuk kegiatan sekolah selalu diarahkan pada peningkatan profesionalisme guru untuk meningkatkan mutu pendidikan agar dapat berkembang dan maju sesuai dengan kebutuhan pembangunan dan perkembangan zaman. (E.Mulyasa, 2004: 83)

Keberadaan SDUT Bumi Kartini Jepara sebagai salah satu pendidikan yang bercirikan keislaman selalu berupaya untuk meningkatkan kualitas mutu pendidikan di Kabupaten Jepara. Kenyataan di lapangan kepala Sekolah SDUT Bumi Kartini Jepara menyadari bahwa setiap program yang telah dibuat untuk peningkatan mutu pendidikan di SDUT Bumi Kartini Jepara dirasa kurang disesuaikan dengan aspekaspek yang kurang menunjang seperti biaya, tenaga pendidikan, buku, input siswa, kurang nya minat guru untuk mengikuti diklat dan workshop yang diadakan oleh pemerintah kabupaten. Untuk itu diperlukan seorang pemimpin yang dapat membuat inovasi-inovasi dan teori paradigma dalam meningkatkan mutu pendidikan di SDUT Bumi Kartini Jepara.

Pada kepemimpinan sekarang SDUT Bumi Kartini Jepara sudah berupaya semaksimal mungkin dalam meningkatkan mutu pendidikan, ini terlihat dari penerimaan siswa baru setiap tahun semakin tinggi, ini bertujuan untuk mendapatkan input siswa yang dari TK memiliki kemampuan dalam penguasaan materi agama maupun umum. Disamping itu juga buku-buku yang berkenaan dengan mata pelajaran sudah dipenuhi semua dari buku umum sampai buku agama, guru-guru sebagai tenaga pendidik selalu diikut sertakan dalam kegiatan workshop, diklat KKG sesuai dengan mata pelajaran masing- masing.

SDUT Bumi Kartini Jepara adalah Sekolah Dasar yang beralamat di jalan Raya Jepara Bangri sudah berupaya menjaga dan meningkatkan kualitas/ mutu pendidikan. Dari permasalahan itulah, penulis merasa tertarik untuk mengadakan penelitian tentang peran kepala Sekolah dalam peningkatan mutu pendidikan, perspektif konsep Manajemen Mutu Terpadu Studi Kasus di SDUT Bumi Kartini Jepara. Sebagai umpan balik bagi program penerapan itu sendiri maupun untuk 
bahan kajian dan perbandingan upaya-upaya serupa di lembaga pendidikan lainnya.

Berdasarkan uraian di atas, maka dapat dibuat beberapa rumusan masalah sebagai berikut: ada dua pokok masalah yang perlu dibahas, pertama, peran kepala sekolah dalam meningkatkan mutu pendidikan di SDUT Bumi Kartini Jepara, dan kedua faktor penghambat dan pendorong apa saja yang dihadapi kepala sekolah dalam meningkatkan mutu pendidikan di SDUT Bumi Kartini Jepara.

\section{LANDASAN TEORITIS}

\section{Hakekat Manajemen Mutu Terpadu}

Manajemen Mutu Terpadu merupakan suatu pendekatan dalam upaya meningkatkan daya saing organisasi melalui perbaikan terus menerus atas produk, jasa, manusia, proses dan lingkungan yang mempunyai prinsip - prinsip utama. Dalam manajemen mutu terpadu pelanggan dan kepentingannya harus mendapat perhatian utama, dan untuk mewujudkan harapan pelanggan, dibutuhkan partisipasi semua pegawai serta dikomandani oleh seorang pemimpin yang mampu menggerakkan pegawai agar mereka memiliki motivasi dan kinerja yang tinggi dalam mencapai tujuan kepuasan pelanggan. Karena pada hakekatnya seorang pemimpin adalah orang yang bisa mempengaruhi dan menggerakkan bawahan.

Manajemen mutu terpadu selain dikenal pada dunia dan industri atau bisnis, manajemen mutu terpadu juga telah memasuki organisasi pendidikan. Dalam paradigma manajemen mutu terpadu, mutu merupakan suatu hal yang dikedepankan, tidak terkecuali pada kegiatan pendidikan. Manajemen Mutu Terpadu merupakan sebuah manajemen yang berorientasi pada peningkatan mutu, baik dari inputs, proses, layanan, maupun outputs, upaya peningkatan mutu ini diarahkan kepada upaya memberikan kepuasan bagi pengguna produk (customers).

Mengenai manajemen mutu terpadu ini, Syaiful Sagala menyatakan bahwa yang menjadi fokus utama dalam model manajemen mutu terpadu adalah proses yang benar dan bermutu untuk memperbaiki material dan jasa pelayanan pendidikan dan ia harus didukung oleh unsur manusia yang professional dan kompeten sebagai pihak yang bertanggung jawab dalam melaksanakan jasa pelayanan pendidikan (Sagala, 2004: 50).

\section{Peran Kepala Sekolah}

Adapun peranan utama pemimpin pendidikan dalam kultur (budaya) mutu yang

> | Nur Rohman| Peran Kepala Sekolah dalam Peningkatan Mutu Pendidikan Perspektif Manajemen Mutu Terpadu Studi Kasus di SDUT Bumi Kartini Jepara 
dipaparkan oleh (Sallis, 1993:173), yaitu :

1. Memiliki visi mutu terpadu bagi institusi

2. Memiliki komitmen yang jelas terhadap proses peningkatan mutu

3. Mengkomunikasikan pesan mutu

4. Memastikankebutuhan pelanggan menjadi pusat kebijakan dan praktek institusi

5. Mengarahkan perkembangan karyawan

6. Berhati hati dengan tidak menyalahkan orang lain saat persoalan muncul tanpa bukti-bukti yang nyata. kebanyakan persoalan yang muncul adalah hasil dari kebijakan institusi dan bukan kesalahan staf

7. Memimpin inovasi dalam institusi

8. Mampu memastikan bahwa struktur organisasi secara jelas telah mendefinisikan tanggung jawab dan mampu mempersiapkan delegasi yang tepat

9. Memiliki komitmen untuk menghilangkan rintangan, baik yang bersifat organisasional maupun kultural

10. Membangun tim yang efektif

11. Mengembangkan mekanisme yang tepat untuk mengawasi dan mengevaluasi kesuksesan

Kepala Sekolah sebagai Pemimpin Pendidikan

Kepala sekolah menjalankan kepemimpinan pendidikan, perlu melakukan beberapa hal penting, sebgaimana ditemukan oleh Sallis (2003). Usaha-usaha itu diantaranya :

1. Melibatkan guru-guru dan semua staf dalam aktivitas penyelesaian masalah dengan menggunakan metode ilmiah, dan prinsip proses pengawasan mutu dengan statistik,

2. Mintalah pendapat dan aspirasi mereka tentang sesuatu dan bagaimana sebuah proyek ditangani, karena itu jangan menggurui mereka,

3. Pahamilah bahwa keinginan untuk perbaikan yang berarti bagi guru-guru tidak cocok dengan pendekatan atas bawah (top down) terhadap manajemen,

4. Pelaksanaan yang sistematik dan komunikasi yang terus menerus dengan melibatkan setiap orang di sekolah,

5. Bangaunlah keterampilan-keterampilan dalam mengatasi konflik penyelesaian masalah dan negosiasi, 
6. Berikanlah pendidikan dalam konsep mutu dan pelajaran seperti membangun tim kerja, proses manajemen, pelayanan pelanggan, komunikasi dan kepemimpinan,

7. Berikanlah otonomi dan keberanian mengambil resiko dari para guru atau staf. Kepala Sekolah sebagai Manajer

Menurut Stoner ada delapan macam fungsi seorang manajer, adapun kedelapan fungsi tersebut yaitu (Wahjosumidjo, 2005:97)

1. Kepala sekolah bekerja dengan dan melalui orang lain (work with and through other people)

2. Kepala sekolah bertanggung jawab dan mempertanggung-jawabkan (responsible and accoutable)

3. Dengan waktu dan sumber yang terbatas seorang kepala sekolah harus mampu menghadapi berbagai persoalan (managers balance competing goald and set priorities).

4. Kepala sekolah harus berfikir secara analistik dan konsepsional (must think analytically and conceptionally)

5. Kepala sekolah sebagai juru penengah (mediators)

6. Kepala sekolah sebagai politisi (politicians)

7. Kepala sekolah sebagai diplomat. Dalam peranan sebagai diplomat dalam berbagai macam pertemuan kepala sekolah adalah wakil resmi dari sekolah yang dipimpinnya.

8. Kepala sekolah berfungsi sebagai pengambil keputusan yang sulit (make difficult decisions)

\section{Fungsi Manajer Perspektif Manajemen Mutu Terpadu}

Perencanaan Mutu

Ada empat pokok yang dapat dijadikan pedoman bagi penyu-sun perencanaan pendidikan, yaitu: (1) contribution to purpose and objectives, (2) primacy of planning, (3) pervasiveness of planning, (4) effciency of planning (Burhanuddin,1994:170-171).

\section{Pengendalian Mutu}

Ada tiga unsur utama dalam fungsi pengendalian yakni (Stoner \& Wankel, 2003:24):

1. Menetapkan standar kinerja (performance)

2. Mengukur kinerja yang sedan berjalan dan membandingkan dengan standar

> Nur Rohman| Peran Kepala Sekolah dalam Peningkatan Mutu Pendidikan Perspektif Manajemen Mutu Terpadu Studi Kasus di SDUT Bumi Kartini Jepara 
yang telah dibakukan;

3. Mengambil langkah-langkah untuk memperbaiki kinerja yang tidak sesuai dengan standar;

Ada 21 asas pokok penerapan pengendalian mutu yang satu sama lain saling melengkapi secara terpadu, yakni (Henryanto \& Marbun,1993:26):

1. Mutu adalah kepuasan pengguna

2. Mutu adalah kepuasan pelanggan

3. Pelanggan adalah proses berikutnya

4. Strategi memasuki pasar bukan sekedar berproduksi

5. Mutu ada pada setiap kegiatan

6. Memecahkan persoalan adalah meningkatkan mutu.

7. Pemecahan persoalan meliputi tindakan penyembuhan dan pencegahan.

8. Berbicara dengan fakta

9. Sedikit tetapi menentukan

10. Pengendalianada pada proses

11. Pengendalian adalah menjalankan PDCA

12. Pengendaliandiawali dengan sasaran struktur

13. Kesinambungan merupakan daya kerja

14. Pembaruan untuk kemajuan

15. Kemajuan melalui pen cata-tan dan standarisasi

16. Kemajuandidukung keikatan dan keterlibatan

17. Pendidikan akan pelatihan merupakan keharusan

18. Pembinaan karyawan oleh organisasi sedangkan pe-ngembangannya oleh gugus

19. Pengendalian mutu terpadu bukan obat tapi alat Analisis

20. Senioritas untuk keselarasan kerja

21. Bekerja dengan tidak saling menyela

Adapun faktor penentu keberhasilan program pengendalian mutu, yakni (Henryanto \& Marbun, 1993:227):

1. Peran karyawan

2. Peran pemimpin

3. Hubungan antara karyawan dan pimpinan

4. Aspek organisasi dan mana-jemenaspeklingkungan kerja

5. Aspek lingkungan kerja 


\section{Perbaikan Mutu}

Ada beberapa pandangan yang mesti diutamakan kepada semua anggota organisasi di dalam menciptakan iklim budaya mutu, yaitu (Gasperz, 2003:157):

1. Hari ini harus lebih baik daripada kemarin, dan hari esok harus lebih baik daripada hari ini.

2. Tidak boleh satu hari-pun yang lewat tanpa perbaikan/ peningkatan.

3. Masalah yang timbul meru-pakan suatu kesempatan untuk melaksana-kan perbaikan / peningkatan.

4. Menghargai adanya perbai-kan/ peningkatan meskipun kecil.

5. Perbaikan/peningkatan tidak harus memerlukan investasi yang besar.

Ada lima aktivitas pokok dalam perbaikan berkesinambungan, yaitu (Tjipto \& Diana, 2002:266):

1. Komunikasi

2. Memperbaiki masalah yang nyata/jelas

3. Memandang ke hulu

4. Mendokumentasikan kemajuan dan masalah

5. Memantau perubahan

\section{Kepemimpinan Manajemen Mutu Terpadu}

Di dalam manajemen mutu terpadu ada beberapa pilar utama untuk menggerakkan suatu organisasi sebagai guru dalam manajemen mutu terpadu. Penelitian Deming, Juran dan Crosby telah mengidentifikasikan bahwa proses perbaikan mutu memerlukan keseimbangan antara perbaikan proses dengan peningkatan sumber daya manusia yang dikendalikan oleh kepemimpinan mutu.

\section{Gaya Kepemimpinan dalam Konteks Manajemen Mutu Terpadu}

Ada beberapa karakteristik penting dari pemimpin transformasional yang diperlukan dalam dinamika perbaikan manajemen mutu terpadu adalah sebagai berikut: (Nasution, 2004: 204-205).

1. Memiliki visi yang kuat.

2. Memiliki peta untuk tindakan.

3. Memiliki kerangka untuk visi (frame for the vision).

4. Memiliki kepercayaan diri.

5. Berani mengambil risiko.

6. Memiliki gaya pribadi yang kuat sehingga membuat pengikut pengikutnya

> Nur Rohman| Peran Kepala Sekolah dalam Peningkatan Mutu Pendidikan Perspektif Manajemen Mutu Terpadu Studi Kasus di SDUT Bumi Kartini Jepara 
merasa dekat dengan pemimpinnya.

7. Memiliki kemampuan mengidentifikasi manfaat- manfaat.

Ciri seorang yang berhasil menerapkan gaya kepemimpinan transformasional (Komariah dan Triatna, 2005: 57) adalah sebagai berikut: (1) mengidentifikasi dirinya sebagai agen perubahan (pembaharu); (2) memilki sifat pemberani; (3) mempercayai orang lain; (4) bertindak atas dasar system nilai (bukan atas dasar kepentingan individu, atau atas dasar kepentingan dan desakan kroninya; (5) meningkatkan kemampuannya secara terus menerus; (6) memilki kemampuan untuk menghadapi situasi yang rumit, tidak jelas, dan tidak menentu; serta (7) memiliki visi kedepan.

\section{Unsur-unsur dalam Manajemen Mutu Terpadu}

Diantara unsur MMT adalah:

1. Fokus pada pelanggan, baik pelanggan internal maupun eksternal

2. Memiliki obsesi yang tinggi terhadap mutu

3. Menggunakan pendekatan ilmiah dalam pengambilan keputusan dan pemecahan masalah

4. Memiliki komitmen jangka panjang

5. Membutuhkan kerja sama Tim (Teamwork)

6. Memperbaiki proses secara berkesinambungan

7. Menyelenggarakan pendidikan dan pelatihan

8. Memberikan kebebasan yang terkendali

9. Memiliki kesatuan tujuan

10. Adanya keterlibatan dan pemberdayaan karyawan

\section{Guru dan Siswa adalah Mitra Kepala Sekolah}

Adanya otonomi pendidikan sekarang ini, membawa dampak yang signifikan terhadap sistem pendidikan yang dijalankan dalam sebuah sekolah. Hal ini berarti sekolah diberikan keleluasaan untuk mendayagunakan sumberdaya yang ada secara efektif. Oleh karena implikasi itu maka sekali lagi peran kepala sekolah sangat dibutuhkan untuk mengelola manusia-manusia yang ada dalam organisasi sekolah, termasuk memiliki strategi yang tepat untuk mengelola konflik. Kepala sekolah akan berhadapan dengan pribadi-pribadi yang berbeda karakter. Mc.Gregor (1960) berasumsi bahwa manusia tidak memiliki sifat bawaan yang tidak menyukai pekerjaan. Dibawah kondisi tertentu manusia bersedia mencapai tujuan tanpa harus dipaksa dan ia mampu diserahi tanggung jawab. Urgensinya bagi kepala sekolah 
adalah menerapkan gaya kepemimpinan yang partisipatif demokratik dan memperhatikan perkembangan professional sebagai salah satu cara untuk memotivasi guru-guru dan para siswa.

Pada konteks manajemen sekolah, semua kegiatan sekolah harus dikelola dengan memanfaatkan semua sumber daya (resources) baik sumber daya manusia, material, dan dana dalam rangka mencapai tujuan dalam berarti pembelajaran efektif dan efesien. Efektifitas dan efisien pencapaian tujuan berarti pembelajaran efektif yang bermuara pada pembelajaran dan pengajaran yang menghasilkan siswa berprestasi tinggi dan lulusan yang bermutu. Untuk itu diperlukan pemikiran bagaimana menciptakan sekolah yang efektif yang mampu menghasilkan mutu lulusan yang lebih baik.

\section{METODOLOGI PENELITIAN}

\section{Pendekatan Penelitian}

Penelitian ini menggunakan pendekatan kualitatif yang maksudnya adalah seluruh komponen data nantinya diekpresikan dalam bentuk kata-kata atau kalimat, tidak dengan angka-angka. Sebagaimana dikemukakan oleh (Nana Sudjana, 1991:195) pendekatan kualitatif adalah ketetapan interpretasi bergantung pada ketajaman analisis, pada bukan sistematika dengan menghitung beberapa besar probabilitasnya.

2. Metode Penelitian

Metode penelitian yang digunakan adalah penelitian deskriptif artinya suatu metode yang menggambarkan fenomena yang ada disertai dengan penjelasan faktor penghambat dan pendukung. Penelitian deskriptif ini merupakan penelitian yang benar-benar hanya memaparkan apa yang terdapat atau terjadi dalam sebuah kancah, lapangan, atau wilayah tertentu (Suharsimi Arikunto, 2010:3).

3. Subyek Penelitian

Adapun subyek dalam penelitian ini adalah Kepala SDUT Bumi Kartini Jepara.

\section{Teknik Pengumpulan Data}

Sesuai dengan bentuk dan jenis penelitian kualitatif dan sumber data yang digunakan, maka teknik pengumpulan data yang digunakan meliputi; Observasi,

> | Nur Rohman| Peran Kepala Sekolah dalam Peningkatan Mutu Pendidikan Perspektif Manajemen Mutu Terpadu Studi Kasus di SDUT Bumi Kartini Jepara 
Dokumentasi dan Wawancara. Dalam mengumpulkan data-data yang diperlukan, maka penulis membutuhkan alat yang berbentuk instrument penelitian.Maka dalam penelitian ini digunakan alat berupa: 1). Pedoman Wawancara, 2). Pedoman Dokumentasi dan 3). Pedoman Observasi.

\section{Keabsahan Data}

Peneliti menggunakan triangulasi sebagai teknik untuk mengecek keabsahan data. Triangulasi dengan sumber juga berarti membandingkan dan mengecek balik derajat kepercayaan suatu informasi yang diperoleh melalui waktu dan alat yang berada dalam penelitian kualitatif (Patton, 1987: 331). Hal itu dapat tercapai dengan berbagai cara, diantaranya sebagai berikut:

1. Membandingkan data hasil pengamatan dengan data hasil observasi

2. Membandingkan apa yang dikatakan orang didepan umum dengan apa yang dikatakannya secara pribadi

3. Membandingkan apa yang dikatakan orang-orang tentang situasi penelitian dengan apa yang dikatakan secara pribadi

4. Membandingkan keadaan dan perspektif seseorang seperti rakyat biasa orang berpendidikan menengah atau tinggi, orang berada, orang pemerintahan dan sebagainya.

5. Membandingkan hasil wawancara dengan isi suatu dokumen yang berkaitan.

\section{Teknik Analisa Data}

Teknik analisis data yang peneliti gunakan adalah menggunakan teknik analisis data kualitatif model Miles dan Hubermen, aktifitas dalam analisis data kualitatif tersebut meliputi tiga tahap yaitu: Pertama, tahap reduksi data (Data Reduction). Kedua, tahap penyajian data (Data Display). Ketiga, tahap penarikan kesimpulan (Verification).

\section{HASIL PENELITIAN}

\section{Peran Sebagai Perencana Mutu}

Di dalam pelaksanaan tugas sebagai kepala sekolah Ernawati, M.Pd dari segi perencanaan bahwa dalam penyusunan sebuah rencana sekolah, kepala sekolah selalu melakukan koordinasi kepada para wakil kepala sekolah yang telah memiliki berbagai tugas masing-masing, sehingga memudahkan kepala sekolah untuk membuat sebuah kebijakan. 
Perencanaan yang dilakukan oleh kepala sekolah selalu melibatkan staf karyawan maupun dewan guru karena selaku kepala SDUT, Ernawati, M.Pd Bumi Kartini Jepara meyakini kebersamaan itu penting untuk mewujudkan SDUT Bumi Kartini yang berkualitas. Perencanaan yang dilakukan oleh kepala SDUT Bumi Kartini didukung penuh oleh guru dan karyawan. (Wawancara kepada Asmal Wafa,S.Pd tanggal 15 Februari 2017).

Ernawati, M.Pd dalam menyusun sebuah perencanaan, lebih dahulu menjelaskan kepada para guru dan karyawan tujuan yang akan dicapai perencanaan yang dijadikan prioritas dalam perencanaan yang telah dibuat. Perencanan dalam sebuah kegiatan, biasanya dibentuk sebuah panitia-panitia yang telah disusun oleh sekolah atau persetujuan kepala sekolah untuk memudahkan kegiatan tersebut dapat berjalan dengan baik dikarenakan adanya dukungan yang nyata dari guru maupun karyawan.

Berdasarkan (wawancara kepada Edi Susilo,S.Pd Kepala TU SDUT Bumi Kartini, tanggal 13 Februari 2017) didapatkan bahwa Ernawati, M.Pd ini menempatkan mutu sebagai prioritas dalam pengembangan sekolah. Kepala SDUT Bumi Kartini Jepara melakukan monitoring dan evaluasi terhadap proses pembelajaran. Monitoring yang telah dilakukan diupayakan untuk memberikan arahan kepada guru dan karyawan dalam melaksanakan tugasnya, sehingga kepala sekolah mengetahui sejauhmana kinerja yangtelah dilakukan. Sedangkan untuk evaluasi yang dilakukan dijadikan sebagai bahan bagi perbaikan kegiatan yang akan datang, dengan adanya evaluasi kepala sekolah dapat memberikan masukan ataupun penilaian terhadap kinerja guru maupun karyawan.

\section{Peran Sebagai Pengendalian Mutu}

Dari segi pengendalian, yang peneliti dapatkan dari hasil wawancara dan observasi kepada dewan guru di SDUT Bumi Kartini Jepara didapatkan data bahwa, program yang dilakukan oleh kepala SDUT Bumi Kartini Jepara salah satunya adalah dengan adanya rapat bulanan yang dilakukan, yang bertujuan untuk mengevaluasi setiap kegiatan yang sedang dilakukan ataupun yang akan dilakukan, tentu saja dengan adanya rapat bulanan ini, setiap program kerja dibahas untuk mendapatkan kesepakatan bersama diantara para guru dan karyawan.

Dari hasil perencanaan, biasanya kepala sekolah memberikan arahan kepada

> | Nur Rohman| Peran Kepala Sekolah dalam Peningkatan Mutu Pendidikan Perspektif Manajemen Mutu Terpadu Studi Kasus di SDUT Bumi Kartini Jepara 
staf dewan guru dan karyawan dalam melaksanakan tugasnya, untuk pedoman kegiatan tentu saja didapatkan dari Dinas Pendidikan sendiri namun untuk kegiatan yang sifatnya jangka pendek pedoman yang bukan tertulis tentunya ada poin-poin pokok yang harus dicapai dalam kegiatan tersebut. (Wawancara kepada Laila Qodrinana, S.Pd, tanggal 13 Februari 2017).

Selanjutnya evaluasi dan monitoring ini dilakukan secara berkelanjutan berdasarkan program yang telah ditetapkan bersama. Selain itu juga, kepala sekolah selalu memberikan reward bagi para karyawan ataupun para guru yang memiliki prestasi dengan diberikannya sertifikat dari kepala sekolah, dan punishment kepada guru dan karyawan yang telah melakukan kesalahan dalam tugasnya namun dalam hal ini punishment yang bersifat pembinaan ataupun dilakukan teguran secara lisan. Untuk menilai kinerja ini, kepala sekolah memiliki penilaian tersendiri secara langsung. Setiap guru ataupun karyawan SDUT Bumi Kartini Jepara melaksanakan tugas dengan arahan kepala SDUT Bumi Kartini Jepara, sehingga pada pelaksanaannya tugas yang telah dilakukan selalu diminta laporan untuk mengontrol kegiatan yang dilakukan. (Wawancara kepada Margo Mulyana, S.Pd, tanggal 13 Februari 2017).

\section{Peran dari Segi Perbaikan Mutu}

Dalam program kerja Ernawati, M.Pd melakukan supervisi setiap per semester yang dilakukan langsung oleh kepala sekolah beserta para wakilnya ataupun guru yang memiliki kemampuan untuk melakukan supervisi. Ini dilakukan bertujuan untuk mengevaluasi hasil kerja selama ini, serta masukan yang akan diberikan kepada guru yang disupervisi demi kepentingan bersama. Namun hasil supervisi ini, ada sebagian guru yang tidak diberitahukan apa-apa saja kekurangan atau kelemahan guru itu dalam proses pembelajaran di kelas, sehingga perbaikan kinerja tugasnya sebagai guru masih belum dapat mencapai apa yang diinginkan oleh sekolah. (Wawancara kepada Laila, tanggal 15 Februari 2017).

Kepala SDUT Bumi Kartini Jepara sudah melakukan perbaikan mutu dalam program kerja yang telah dibuat. Berdasarkan penjelasan dari Ernawati, M.Pd dari segi meningkatkan kemampuan guru dan karyawan diberi kesempatan suatu pelatihan untuk meningkatkan kemampuan guru dan karyawan tersebut baik itu diluar maupun di dalam institusi pendidikan.

Selain itu juga di dalam peningkatan mutu pendidikan di SDUT Bumi Kartini 
Jepara, Program kerja dari kepala SDUT Bumi Kartini Jepara, mengadakan bimbingan mengadakan bimbingan belajar yang dilakukan pada waktu jam pulang sampai selesai yang dilakukan 3 kali dalam seminggu, pada program ini siswa diberikan pelajaran tambahan untuk menunjang pelajaran di sekolah. (Wawancara kepada Margo Mulyono, S.Pd, tanggal 13 Februari 2017).

\section{Faktor-faktor Penghambat dan Pendorong Peningkatan Mutu Pendikan}

Hambatan yang dihadapi Kepala SDUT Bumi Kartini Jeparadalam menerapkan kinerja kepemimpinannya dalam rangka mewujudkan Visi dan Misi sekolah atau peningkatan mutu sekolah adalah:

1. Masih adanya tenaga pegawai yang kurang tanggap untuk menjalankan tugas secara baik;

2. Masih kurangnya tenaga pendidik/guru tetap;

3. Anggaran keuangan yang terbatas;

4. Sarana prasarana belajar mengajar masih belum memadai.

Walaupun demikian keadaannya, Kepala SDUT Bumi Kartini Jepara dalam meningkatkan mutu pendidikan tetap menggerakkan bawahannya untuk bekerja secara produktif dengan cara melakukan pendekatan sebagai berikut:

1. Pendekatan persuasif dimana Kepala Sekolah membangun sebuah hubungan yang harmonis antar bawahan, hal ini dilakukan agar tidak ada salah satupun komponen yang mengalami kelesuan dalam menjalankan tugasnya.

2. Pendekatan partisipatif atau demokratis yaitu dengan melibatkan semua komponen ikut terlibat dalam setiap kegiatan dan permasalahan, sehingga mereka dapat mem-bangunopini kesuksesan atau hasil kerja bersama dan bukan hanya hasil kerja Kepala Sekolah, sehingga mereka bertanggung jawab akan citra Sekolah dan dunia pendidikan.

3. Pendekatan emosional yaitu pendekatan yang terbangun dari individu dimana pendekatan sebelumnya bukanlah sebuah paksaan.

Selain pendekatan tersebut, Kepala SDUT Bumi Kartini Jepara juga memiliki cara dalam meningkatkan mutu pendidikan yaitu dengan cara:

1. Memberikan reward kepada guru yang ber-prestasi

2. Melakukan evaluasi dan pengontrolan terhadap bawahan sehingga jika terdapat bawahan yang kurang aktif dapat dilakukan pembinaan dan arahan agar dapat melaksanakan kegiatan dengan baik.

> Nur Rohman| Peran Kepala Sekolah dalam Peningkatan Mutu Pendidikan Perspektif Manajemen Mutu Terpadu Studi Kasus di SDUT Bumi Kartini Jepara 
3. Menyediakan fasilitas sehingga mempermudah kegia-tan para guru dan karyawan dalam melaksanakan tugas.

Selanjutnya faktor pendukung atau pendorong Kepala SDUT Bumi Kartini Jepara dalam meningkatkan mutu pen-didikan di SDUT Bumi Kartini Jepara adalah sebagai berikut:

1. Faktor individual, yaitu sikap, kemampuan dan motivasi yang tinggi untuk berprestasi dalam tugas;

2. Dukungan yang di dapat dari bawahan (guru dan pegawai) karena mampu menciptakan suasana sekolah yang dinamis dan harmonis melalui pende-katanpendekatan dan budaya disiplin, kerjasama serta kekeluargaan yang dibangun;

3. Dukungan dari komite Sekolah, Yayasan dan masyarakat karena mampu membangun hubungan dan kerjasama dengan cara meli-batkan mereka dalam berbagai persoalan yang dihadapi dan menerapkan manajemen terbuka;

Pekerjaan yang menantang, untuk mewujudkan komitmen bersama sekolah yaitu visi dan misi SDUT Bumi Kartini Jepara.

\section{SIMPULAN}

Setelah menganalisa data yang diperoleh, dapat disimpulkan bahwa:

1. Peran Kepala SDUT Bumi Kartini Jepara dalam meningkatkan mutu pendidikan perspektif konsep manajemen mutu terpadu sudah melakukan dengan baik yaitu: Pertama, peran sebagai perencanaan mutu kepala SDUT Bumi Kartini Jepara melakukan koordinasi kepada seluruh staf karyawan dan juga dewan guru dalam melakukan kegiatan, melibatkan seluruh komponen, menjelaskan tujuan yang akan dicapai, membentuk panitia-panitia, mengadakan monitoring dan mengadakan musyawarah setiap mau melakukan kegiatan. Kedua, peran sebagai pengendalian mutu kepala SDUT Bumi Kartini Jepara dalam hal ini adalah Ernawati, M.Pd yang dilakukan adalah mengadakan evaluasi kinerja, membandingkan kinerja aktual dengan target, mengadakan rapat bulanan, menetapkan standar khusus dalam kinerja, memberikan reward dan punishment, memberikan arahan kepada pegawai, meminta laporan setelah kegiatan dan selalu memberikan motivasi kepada staf karyawan maupun dewan guru. Ketiga, peran sebagai perbaikan mutu dalam hal ini kepala SDUT Bumi Kartini Jepara mengadakan perbaikan terus menerus, mengadakan supervisi setiap persemester, memberikan pelatihan dan pendidikan kepada guru dan pegawai, 
mengadakan bimbingan belajar siswa pada jam luar sekolah dan bekerja sama dengan orang tua murid.

2. Faktor penghambat dan pendorong kepala SDUT Bumi Kartini Jepara dalam meningkatkan mutu pendidikan: Faktor penghambat yaitu: masih ada pegawai yang kurang tanggap dalam menjalankan tugas, kurang tenaga pendidik, anggaran keuangan yang terbatas, dan sarana prasarana belajar yang kurang memadai. Faktor pendukung, yaitu: faktor individual diantaranya sikap dan kemampuan dan motifasi yang tinggi untuk berprestasi dalam tugas, dukungan yang didapat dari bawahan, dukungan dari komite sekolah dan masyarakat setempat.

\section{DAFTAR PUSTAKA}

Abu Bakar,Usman dan Surohim. 2006. Fungsi Ganda Lembaga Pendidikan Islam, Yogyakarta: Safira Insani Press

Abrasyi, Mohd Athiyah, Al. 1993. Dasar-dasar Pokok Pendidikan Islam. (terj.) Bustami A. Ghani dan Djohar Bahri. Dari judul asli al-Tarbiyah al-Islamiya wa Fulasifatuha. Jakarta: Bulan Bintang

Anastasia, Fandy. 2002. Fungsi-Fungsi Manajerial Menurut Manajemen Mutu Terpadu. Bandung: Yayasan Amal Keluarga

Arikunto, Suharsimi. 2010. Prosedur Penelitian Suatu Pendekatan Praktik. Jakarta: PT Rineka Cipta

Bafadal. 1992. Perencanaan Pendidikan Teori dan Metodelogi. Jakarta: P2IPTK

Burhanuddin.1994. Analis Administrasi, Manajemen dan Kepemimpinan. Jakarta: Bumi Aksara

Bush, T \& Coleman, M. 2012. Manajemen Mutu Kepemimpinan Pendidikan Panduan Lengkap Kurikulum Dunia Pendidikan Modern. Jogjakarta: IRCiSoD

Danim, Sudarwan. 2002. Inovasi Pendidikan dalam upaya peningkatan profesionalisme Tenaga Kependidikan. Bandung: Pustaka Setia

Djamarah, dkk. 2002. Manajemen Pembangunan Kurikulum. Bandung: Remaja

Rosdakarya

Faisal, Sanapiah. 1999. Format-Format Penelitian Sosial. Jakarta: PT. Raja Grafindo Faizaluddin. 2005." Potensi Penerapan TQM pada MAN di Kota Palembang". Tesis Mahasiswa Pasca Sarjana IAIN Raden Fatah.

Fajar, Malik.1999. Reorientasi Pendidikan Islam. Jakarta: Fadjar Dunia

> | Nur Rohman| Peran Kepala Sekolah dalam Peningkatan Mutu Pendidikan Perspektif Manajemen Mutu Terpadu Studi Kasus di SDUT Bumi Kartini Jepara 
Fathurrohman. 2007. Landasan Manajemen Pendidikan . Bandung: Remaja Rosdakarya

Gasperz, Vincint. 2001. Total Quality Management. Jakarta: Gramedia Pustaka Utama . 2003. Total Quality Management. Jakarta: Gramedia Pustaka Utama 2005. Total Quality Management. Jakarta: PT. Gramedia,

Hadis, A. H dan Nurhayati, B. 2012. Manajemen Mutu Pendidikan. Bandung: Alfabeta

Hamid, A. 2010. Aplikasi Total Quality Management (TQM) Pendidikan Tinggi Dalam Rangka Pelayanan Pelanggan Mahasiswa Asing di International Islamic. Jakarta: PT. Gramedia

Hannaway and Carnoy. 1995. Decentralization and School Implovement: Can We Fulfil the promise. San Francisco: Jossey Bass Publishers Hardjosoedarmo, Soewarso. 2004. Totall Quality Manajement. Yogyakarta: ANDI Ismanto, Kuat. 2009. Manajemen Syari'ah Implementasi TQM dalam Lembaga Keuangan Syari'ah. Yogyakarta: Pustaka Pelajar

Jalal, F dan Supriadi, D. 2001. Reformasi Pendidikan dalam Konteks Otonomi Daerah. Jakarta: Adicita Karya Nusa

Marbun, Henryanto. 1993. Manajemen Mutu Sekolah.Jakarta: Grasindo 